\title{
Host immune responses to the itch mite, Sarcoptes scabiei, in humans
}

\author{
Sajad A. Bhat", Kate E. Mounsey, Xiaosong Liu and Shelley F. Walton
}

\begin{abstract}
Scabies is a parasitic disease due to infestation of skin by the burrowing mite Sarcoptes scabiei. Scabies is a major public health problem and endemic in resource poor communities worldwide affecting over 100 million people. Associated bacterial infections cause substantial morbidity, and in severe cases can lead to renal and cardiac diseases. Mite infestation of the skin causes localised cutaneous inflammation, pruritus, skin lesions, and allergic and inflammatory responses are mounted by the host against the mite and its products. Our current understanding of the immune and inflammatory responses associated with the clinical manifestations in scabies is far outweighed by the significant global impact of the disease. This review aims to provide a better understanding of human immune responses to $\mathrm{S}$. scabiei in ordinary and crusted scabies phenotypes.
\end{abstract}

Keywords: Sarcoptes scabiei, Scabies, Crusted scabies, Immune responses, Cytokines

\section{Background}

Scabies is an infestation of the skin caused by the burrowing ectoparasitic mite called Sarcoptes scabiei variety hominis (Greek word 'sarx' means flesh; 'koptein' means to smite or to cut and the Latin word 'scabere' means to scratch) [1]. It was reported in 2010 that about 100 million of the global population is infected with scabies [2] and prevalence in different regions ranged from 0.2 to $71.4 \%$ [3]. Scabies has been found to be more prevalent in developing countries and has a high impact on the health and social life of indigenous populations in developed countries [2]. In particular, countries of the Pacific and Latin American regions have a high burden of scabies and prevalence is substantially higher in children than in adolescents and adults $[2,3]$. The global burden of scabies is reflected by the disability-adjusted life years (DALYs), a measure of health loss due to a disease or injury. One of the leading causes of skin-related DALYs in 2010 was scabies, with around 1.5 million DALYs attributable to scabies alone [4]. In addition to this direct burden, scabies is also linked to secondary complications such as rheumatic heart disease (RHD) and acute poststreptococcal glomerulonephritis (APSGN) [5]. These

\footnotetext{
* Correspondence: s_b121@student.usc.edu.au

Inflammation \& Healing Research Cluster, School of Health and Sport

Sciences, Faculty of Science, Health, Education and Engineering, University of the Sunshine Coast, Locked Bag 4, Maroochydore DC, QLD 4558, Australia
}

secondary complications if left untreated can lead to the development of serious downstream systemic and lifethreatening conditions [6].

People with scabies suffer from intense itching mediated through allergic and inflammatory reactions mounted by the host against the mite and its products. A wide range of clinical features, from mild to severely destructive, occurs in scabies but despite the significant worldwide impact of the disease, the immune and inflammatory responses associated with the different clinical manifestations remain poorly characterized. This review focuses on the recent data which expands our knowledge of cellular and molecular mechanisms in immune responses to S. scabiei in Ordinary scabies (OS) and Crusted scabies (CS) in humans. In addition, the current understanding of scabies immunity will be compared and contrasted to responses in related parasitic infections and infestations.

\section{Clinical manifestations of scabies}

Although a range of clinical presentations are apparent in scabies, for the purpose of this review we consider the two most commonly reported manifestations: OS (also known as classical or typical scabies) and CS (also known as Norwegian scabies, or scabies crustosa).

Ordinary scabies is the common form of scabies with a mite burden estimated to be less than 15 mites per 
person [7]. The main clinical signs include burrows, erythematous papules, and an allergic type skin reaction with intense, generalised pruritus. Occasionally, patients are asymptomatic [8]. Onset of the symptoms in a host with no previous infestation is delayed and occurs at 4 to 6 weeks' post-infestation [9]. The primary papules may develop into secondary scabies lesions: excoriations and eczematisations. Patients usually show primary and secondary lesions existing together at the same time. Due to severe itching patients scratch the skin, opening up the lesion and making them susceptible to secondary bacterial infection.

Crusted scabies is relatively rare and an extreme manifestation with thousands of mites present which are same variant as those causing OS [10]. Due to the high number of mites present, CS is highly contagious as evidenced by nosocomial outbreaks of OS from index cases of CS [11]. Clinically, CS is a hyperkeratotic skin disease with thick and scaly crusts containing large numbers of mites. In CS patients, the infectivity persists for longer because of the difficulty in eradicating mites from heavily crusted skin. Mite reinfestation frequently occurs in the same individual and it is extremely debilitating and can cause permanent skin disfiguration. Crusted scabies patients may show deep fissuring of the crusts with pathogenic microbes gaining entry through these skin breaches and leading to serious secondary infections, frequently with the typical skin pathogens Staphylococcus aureus and Streptococcus pyogenes. Generalized lymphadenopathy due to secondary sepsis is common carrying high mortality rate if left untreated $[9,12,13]$.

It is generally believed that immunosuppression and immunomodulation might be predisposing factors associated with CS. Crusted scabies has been shown in immunocompromised patients such as those with human immunodeficiency virus (HIV) infection [12], human T-lymphocytic virus 1 (HTLV-1) infection [14, 15] and in patients undergoing organ transplantation [16]. In addition, CS has been diagnosed in individuals with leprosy [14] and developmental disability, including Down's syndrome, although the specific mechanisms linking these immune defects to crusted scabies have not yet been explored. Importantly, CS has also been detected in patients with no recognised immunodeficiency as evidenced in Aboriginal Australians [14, 17]. From these reports, it appears that the susceptibility of this cohort to CS may be due to a specific immune deficit, the nature of which is yet to be defined.

\section{Immune response in scabies}

In animals, S. scabiei infestation (sarcoptic mange) results in inflammatory and adaptive immune responses relatively late in the infection (4-6 weeks after initial contact with mite), in contrast to related psoroptic mange where inflammatory responses are seen almost immediately after mite infestation. Given the parasite's long co-evolution with its hosts, it is believed scabies mites have developed the capability of modulating various aspects of the host immune responses resulting in the delayed onset of symptoms [18, 19]. The rash and itch associated with scabies shows features of both type I (immediate) and type IV (delayed) hypersensitivity reactions. The initial inflammatory response as reviewed by Walton et al. [20] towards the mite and its products consists of Langerhans cells (LCs) and eosinophils with smaller number of monocytes, macrophages and mast cells.

\section{Innate immune responses \\ Complement system}

The complement system is an essential and a farreaching component of innate immunity and is the first line of defence against invading pathogens. It consists of almost 40 plasma and membrane associated proteins and together this complex network represents one of the major effector mechanisms of the innate immune system [21]. Complement proteins have been documented in host defence against blood-feeding ticks [22] and also in immune response to other pathogens [23]. Studies analyzing skin biopsies and circulating serum from scabies patients have revealed presence of complement components C3 and C4 [14, 24] suggesting both local and systemic sources of complement during infection. Complement fragments $\mathrm{C} 3 \mathrm{a}$ and $\mathrm{C} 4 \mathrm{a}$ act on specific receptors causing local inflammatory responses. In addition, C3a and C5a can activate mast cells to release mediators such as histamine and tumour necrosis factor alpha (TNF- $\alpha$ ) that contribute to the inflammatory response [25]. The observation of these components in skin biopsies of CS patients [14] indicate an activated complement system which may be participating in the early inflammatory responses in scabies. Somewhat counterintuitively, low circulating $\mathrm{C} 3, \mathrm{C} 4$, or both have been reported in CS patients [14], suggesting some potential defect with complement function in CS, or possibly due to massive overload of mites and bacteria the system is unable to maintain production. Furthermore, there is evidence of scabies mite inactivated protease paralogues (SMIPPs) and serpins (SMSs) inhibiting complement activation and promoting bacterial growth in vitro, presumably protecting mites from complement mediated destruction $[26,27]$. As suggested [28], production of such inhibitory molecules might be a way to evade host defence and also by promoting bacterial growth might provide further mechanisms contributing in disease pathogenesis. While these mechanisms still need to be defined in vivo, a recent study in a porcine model demonstrated the influence of scabies infestation on skin microbiota, with the microbial population changing from commensal to more pathogenic staphylococcal species [29]. Such studies are beginning to provide 
biological insights into the close association between scabies and bacterial skin infection.

\section{Innate immune cells}

The various innate effector cells detected in response to S. scabiei mites in OS and CS include eosinophils, mast cells, basophils, neutrophils, dendritic cells (DCs) and macrophages (Table 1). Eosinophils are produced in high numbers in allergic inflammation and helminth infections, and tissue eosinophilia is often found at inflammatory sites associated with these diseases [30]. Histological examination of 25 skin biopsies of scabies infection has shown the presence of dermal eosinophils in 22 patients with $68 \%$ of these showing numerous eosinophils and $20 \%$ of cases showing few eosinophils [31]. In CS, skin biopsy sections from two patients have shown large numbers of eosinophils in the dermis [24] and 58\% of a cohort of CS patients were reported to have peripheral eosinophilia [14]. In Psoroptes ovis infested sheep and cattle, lesional histology studies also show an eosinophil dominated immunoinflammatory infiltrate [32, 33]. In addition, eosinophil infiltrations have been detected in the skin dermis of red foxes infested with S. scabiei [34]. This eosinophil detection is consistent with the high expression of $\mathrm{T}$ helper (Th) 2 representative cytokines interleukin (IL) 4, IL-5 and IL-13 in CS [35]. Eosinophils have been shown to express Th2 specific cytokines. IL-5 is involved in the attraction, activation and maturation of eosinophils and its production may be an autonomous mechanism for promoting the recruitment and survival of these granulocytes $[30,36]$. The presence of eosinophils in CS and their ability to express Th2 profile cytokines [37] suggests that these granulocytes may themselves modulate or sustain the local Th2 inflammatory responses $[38,39]$ in scabies. Eosinophils may also regulate Th1 inflammatory response. Eosinophils have been shown to produce IL-12 and interferon gamma (IFN- $\gamma$ ) [40], and express several Toll-like receptors (e.g. Toll-like receptor 7) [41] which are part of innate immunity and responsible for Th1 biased responses. Furthermore, it is also suggested that eosinophil expression of IL-10 and transforming growth factor beta (TGF- $\beta$ ) may suppress local inflammatory responses by modulating the activities and development of regulatory $\mathrm{T}$ cells (Tregs). Alternatively, cytokine IL-2 is highly important in the development and survival of Treg cells [42] and eosinophil expression of IL-2 can result in the expansion of these T lymphocytes. In addition, eosinophil production of IL-10 and TGF- $\beta[40,43]$ may alter the local character of the Th2/Th1 responses by preventing the differentiation of naïve $\mathrm{T}$ lymphocytes to either the Th1 or Th2 phenotype [39]. By producing indoleamine 2, 3, -dioxygenase eosinophils may also drive Th1/Th2 imbalance [39]. Eosinophils are key players in defence against helminthic parasites but also contribute to tissue dysfunction and damage in allergic disease. However, the function and relative importance of eosinophils in the immune and inflammatory responses of both ordinary and crusted scabies is still undetermined.

Mast cells and basophils share morphological and functional similarities and are essential components in immunoglobulin (Ig) E mediated allergic diseases and the immune response to parasitic infections. Mast cells and basophils have been detected in skin lesions of scabies patients $[44,45]$, and in sheep with psoroptic mange [32]. In pigs, immunohistochemistry of skin lesions has revealed increased mast cells numbers in CS while their number remained steady over the course of infestation in OS [46]. A recent histological analysis of skin lesions of 86 red foxes with sarcoptic mange have shown numerous mast cells [47] and mast cells have also been detected in the dermis of free-living wombats with severe sarcoptic mange compared to normal wombats [48]. Upon activation, mast cells and basophils rapidly produce TNF- $\alpha$, IL-6, Th2 cytokines IL-4, IL-5 and IL-13, which are the main molecules responsible for the allergic Th2-type inflammation [30, 49]. The mechanisms for the infiltration of mast cells and basophils into the blood and skin remains to be addressed to elucidate their role and importance in scabies inflammatory and allergic responses.

Macrophages, neutrophils, and DCs are immune effector cells involved in phagocytosis, antigen presentation

Table 1 Immune response in scabies

\begin{tabular}{|c|c|c|}
\hline & Ordinary scabies (OS) & Crusted scabies (CS) \\
\hline $\begin{array}{l}\text { Skin cellular } \\
\text { responses }\end{array}$ & Mostly CD4 ${ }^{+} \mathrm{T}$ cells, eosinophils and macrophages [24] & $\begin{array}{l}\text { Mostly CD8 }{ }^{+} T \text { cells, increased } \gamma \delta^{+} T \text { cells, eosinophils and few } \\
\text { macrophages }[14,24,35,88]\end{array}$ \\
\hline $\begin{array}{l}\text { Blood cell } \\
\text { responses }\end{array}$ & T and B cells and T-cell subsets within normal ranges & $\begin{array}{l}\text { T and B cells and T-cell subsets within normal ranges. Increased } \\
y \delta^{+} T \text { cells, eosinophilia }[24,88]\end{array}$ \\
\hline $\begin{array}{l}\text { Th1/Th2 } \\
\text { responses }\end{array}$ & $\begin{array}{l}\text { Th1 mediated with increased production of Th1 cytokines IFN- } \gamma \text {, IL-2 } \\
\text { and TNF-a }[35,46,51] \text {. Increased production of IL-10 [51] }\end{array}$ & $\begin{array}{l}\text { Th2 mediated with increased production of Th2 cytokines } \\
\mathrm{IL}-4, \mathrm{IL}-5 \text { and } \mathrm{IL}-13[14,35,46] \text {. } \\
\text { Increased production of Th17 cytokines } \mathrm{IL}-17, \mathrm{IL}-23[46,88] \text {. } \\
\text { Decreased production of } \mathrm{IL}-10[24,35]\end{array}$ \\
\hline $\begin{array}{l}\text { Systemic lg } \\
\text { responses }\end{array}$ & $\begin{array}{l}\text { Variable reports of elevated levels of total } \lg G, \lg E, \lg A \text { and } \lg M \text {. } \\
\text { Increased levels of scabies-specific } \lg E, \lg G \text { and } \lg A[24,35]\end{array}$ & $\begin{array}{l}\text { Increased levels of total lgG, IgG1, IgG3, lgG4, IgE and IgA. } \\
\text { Elevated levels of scabies specific } \operatorname{lgG} 4, \lg E \text { and } \lg A[24,35]\end{array}$ \\
\hline
\end{tabular}


and differentiation of $\mathrm{T}$ cells. These cells are associated with pro-inflammatory and allergic responses, parasitic infections and possibly humoral responses. IL-4, IL-13, TNF and IFN- $\gamma$ play a role in alternative macrophage activation [50] and these cytokines have been reported in immune response to scabies [24, 35, 46, 51]. Macrophages, although in low numbers, have been detected in skin of patients with scabies [24] and cellular infiltrates of skin lesions in dogs infested with scabies mites $[52,53]$. Low number of macrophages may be due to the production of immune modulating molecules secreted by the scabies mites. It has been suggested that early in the infestation mites inhibit the ability of macrophages to migrate to the site of inflammation allowing the mites to grow and establish [19].

Neutrophils are an essential part of the innate immune system. They drive the initiation of inflammation and are implicated as mediators of tissue-destructive events in various inflammatory diseases as previously reviewed $[54,55]$. In a recent study, histological findings of skin lesions in 44 cases of bullous scabies revealed neutrophils as the predominant inflammatory cell infiltrates [56]. In another similar study, 25 skin biopsies obtained from scabies patients showed the presence of dermal neutrophils in 52\% of cases [31]. Neutrophils have also been detected in inflammatory infiltrates in the skin of common wombats, sheep and red foxes infected with $S$. scabiei [34, 48, 57]. In an in vitro study using human whole blood, with Staphylococcus aureus, the recombinant S. scabiei mite protein SMSB4 was found to suppress bacterial killing by inhibiting opsonisation and phagocytosis by neutrophils [27].

Dendritic cells are among the first skin antigen presenting cells to come into contact with antigens, migrate to draining lymph nodes and process the antigens for presentation to effector $\mathrm{T}$ cells which results in $\mathrm{T}$ cell differentiation and activation. These cells are responsible for pathologies in infections, inflammatory disorders and have also been implicated in modulating the balance between immunity and peripheral tolerance [58, 59]. Histological analysis of the scabietic lesions of dogs have revealed infiltration of DCs in the skin epidermis [53] and DCs derived from human peripheral blood mononuclear cells (PBMCs) have been shown to secrete proinflammatory cytokines upon stimulation with scabies mite extract [60]. This engagement of DCs, neutrophils and macrophages in scabies warrants further investigations into their function, role and importance in immune and inflammatory responses in scabies mite infestations.

\section{Humoral immune responses}

Scabies mite infestation is known to elicit robust antibody-mediated immune responses, especially in
CS which is associated with extremely high levels of antigen specific IgG and IgE (Table 1). However, the timing of these responses, and their relative importance in establishing protective immunity remains poorly understood.

\section{$\lg M$}

IgM is the first antibody to appear in response to antigen exposure and hence is traditionally considered the first line of the humoral immune response. In a recent study, ELISA analysis of serum in OS patients showed IgM antibodies that bound to scabies antigens in $74 \%$ of cases, although a canine antigen mite extract (S. scabiei var. canis) was used, and high cross-reactivity between antigens of scabies and house dust mites was shown which somewhat confounds the interpretation of this finding [61]. Nevertheless, these results suggest that IgM may be useful in detecting serum IgM to scabies antigens. IgM is the first antibody class to be produced and may allow earlier detection of scabies. However, given its low affinity for antigens and the cross-reactivity between house dust and scabies mite proteins the utility of IgM for serodiagnosis of scabies should be further investigated.

\section{$\lg A$}

Secretory IgA is usually more abundant in mucosal regions than in serum and plays a critical role in immune function in the mucous membranes. In OS, it is not clear whether scabies-associated IgA secretion is increased or decreased as compared to non-infected individuals or CS, as studies have reported contradictory results [62-64]. Elevated levels of circulatory IgA were documented in $64 \%$ of study patients with CS [14]. In addition, Walton et al. [35] showed increased IgA binding to a recombinant scabies mite antigen in OS and CS patients compared to controls. In porcine studies, increased IgA serum levels in mange positive pigs was reported to whole mite antigen extract, with significant levels detected at week 10 in the infection and positively correlated with severity of infestation [65].

\section{$\lg G$}

In animals, studies have demonstrated elevated serum levels of total IgG as compared to the controls in S. scabiei var. canis infested rabbits and dogs [62, 66-68]. Serum studies involving whole mite extracts of S. scabiei var. suis and Sars s 14.3 recombinant antigen demonstrated increased IgG, IgG1 and IgG2 responses in mange infected pigs from weeks $6-12$ post-mite infestation [65]. Sarcoptes scabiei var. ovis primary infestation in sheep resulted in significant increases in the serum levels of specific IgG [69]. In the same study, secondary challenge in sheep induced a decreased IgG response in comparison to those observed during the primary infestation [69]. In goats with sarcoptic mange, analysis of 
antibody profiles has revealed a strong serum IgG response in primary infestation and repeated mite experimental challenges [70, 71]. In contrast, goats vaccinated with specific S. scabiei mite antigens showed high levels of scabies-specific IgG in the serum but this vaccination failed to provide protection against infestation despite the presence of elevated levels of IgG [70]. Further studies in dogs, where the IgG titres were inversely proportional to protection, also suggested that IgG antibodies conferred limited protection to sarcoptic mange in dogs [72], with similar conclusions in rabbits [62, 73]. These results also suggest that cell-mediated immune responses may be providing immune protection. In humans, mite infestations result in circulatory IgG responses in both OS and CS $[24,35,74,75]$ with CS patients showing stronger IgG responses compared to OS [74]. Increased serum levels of total IgG were reported in 56 of 58 of cases with CS [14]. On the other hand, only $27 \%$ of patients with OS showed circulatory IgG response directed at scabies mite antigens although S. scabiei var. canis mite extract was used which might limit sensitivity [61]. IgG subclass serology investigations have revealed elevated levels of total and antigen-specific IgG1, IgG3 and IgG4 in CS patients compared to non-infected controls [24, 35, 75]. Serum IgG4 levels are similarly elevated in chronic helminth and other parasite infections and also rise during allergy desensitization therapy, after repeated exposure to low doses of allergen [76]. The reason behind these elevated levels of total IgG and IgG isotypes especially in CS is unknown and may be due to high antigenic load imparted by mite hyper-infestation. Increases in total IgG could also result from concomitant bacterial infections [35]. Increased expression of IgG4 is likely due to the production of IL-4 and IL-13 in CS [14, 35] as these cytokines are known to drive antibody class switching and induce expression of IgG4 [77].

\section{$\lg E$}

IgE is important in the host defence against to a variety of parasites and along with mast cells, basophils, and eosinophils, constitutes an essential element in allergic and parasitic inflammation. In humans, earlier studies have shown that scabies results in an increased production of circulating IgE antibodies but with highly divergent results $[14,63,78,79]$. In recent studies, increased total IgE levels have been observed in OS patients [24, 51]. In a more recent study, ELISA analysis revealed only $2 \%$ of 91 cases with OS had circulating IgE antibodies that bound to S. scabiei var. canis antigens [61]. Conversely, OS patients from Australia had increased IgE antibodies specific to recombinant scabies antigens compared to naïve controls [35]. In another similar study, IgE binding to recombinant scabies mite antigen (Sar s 14) for OS was higher compared to controls, with a $100 \%$ diagnostic sensitivity and $94 \%$ specificity [80]. Furthermore, IgE binding to another scabies mite recombinant antigen was observed in patients with OS from Pakistan, and the ELISA used for detection showed high (over 90\%) sensitivity and specificity ( $\mathrm{Naz} \mathrm{S}$, personal communication). In comparison, in CS dramatic increases in total IgE levels have been consistently reported $[24,74]$ with one study showing $96 \%$ of 56 cases had elevated total IgE levels [14]. Immunoassay studies using plasma from subjects with CS showed increased specific IgE response to recombinant scabies mite molecules [35, 80]. Similar to IgG responses, as suggested by Roberts et al. [14] these results of increased IgE response in CS individuals are expected given the high amount of antigenic material/ stimuli provided by the large number of mites. In the earlier studies reporting variable IgE changes, specific IgE responses to scabies mite antigens were not determined. In addition, altered serum IgE levels could be attributed to the different techniques and antigenic compositions of whole mite extracts used. For example, antigenic similarities exist between scabies and house dust mites, and IgE antibody cross-reactivity has been demonstrated [81, 82]. Hence studies using whole mite extracts may reflect a component of cross-reactive IgE binding. In contrast, the recent ELISA studies using various scabies mite-specific recombinant antigens show high specificity and sensitivity in IgE detection in both OS and CS phenotypes from different populations/ demographics indicating their potential for serodiagnosis of scabies.

In animals, S. scabiei var. canis infestation in rabbits and dogs resulted in elevated serum levels of specific IgE [62, 66-68]. In sheep, primary S. scabiei var. ovis infestation resulted in significant increases in the serum levels of specific IgE and in secondary challenge a higher IgE response was observed than during the primary infestation [69]. In goats with sarcoptic mange, studies have demonstrated a strong IgE response in primary infestation and repeated mite experimental challenges [70]. IgE responses in pigs to S. scabiei mite infestation have not been explored as there is no porcine-specific IgE antibody commercially available.

While the above studies provide some insights into the humoral immune responses of scabies, a major limitation is the absence of robust prospective studies of human infestation. Such studies are difficult to perform due to the delayed appearance of symptoms and ethical considerations. Moreover, sensitivity is decreased when using non var. hominis mite antigen extracts, but obtaining sufficient amounts of scabies mites from human patients for research purposes to generate such extracts is logistically difficult, although recombinant antigens have been utilised $[35,65]$. To further understand the humoral response in scabies it remains important to 
investigate the timing of onset of each Ig response; Ig profiles early in the infestation; after treatment and in reinfection; in both humans, and in suitable animal models; and the relationship between different antibody responses and their role in immunity. This information would be helpful for the development of improved diagnostic tools which would facilitate improved treatment and control of scabies at both the individual and community level.

In summary, in CS significantly higher levels of total and scabies-specific IgE and IgG antibody responses have been observed in comparison to OS where weaker and more varied responses are documented. From these studies, it also appears that differences may exist between the immune responses of humans and other animals to scabies, between primary and secondary infestations. These responses might also be affected by the sex of the host [71], type of infestation in humans (ordinary versus crusted) and the validity of the antigen used for diagnosis. Also, it seems that in some individuals/animals ineffective/dysregulated immune responses result in reduced acquired immunity to mite infestation [34, 71]. In addition, immunomodulation exerted by the mites appear to affect the immune response to infestation $[18,19,83,84]$. This might explain why some animals/individuals fail to develop resistance to reinfection by $S$. scabiei and remained fully susceptible to recurrence of sarcoptic mange/scabies [34]. Also, this dysregulated/ineffective immune response early in the infestation in some individuals/animals might be playing a role in disease susceptibility especially to CS phenotype and the effects of these factors still need to be fully explored.

Elevated IgE and IgG responses have also been observed in parasitic infections such as in schistosomiasis and lymphatic filariasis [85-87] conferring protective immunity. However, the increased IgE and IgG scabies-specific antibody responses seen in CS seems not to be effective at clearing the scabies parasite, as shown by high rates of reinfestation [14] despite these increased antibody levels. It is suggested [14] that these increased serum levels of nonprotective IgE and IgG in CS might be related to an inappropriate Th2 biased immune response but the reasons for this remain unknown.

\section{Cell-mediated immune responses}

\section{$T$ cell infiltrates in S. scabiei-infested skin}

$\mathrm{T}$ cell infiltrates to scabies mite infestation (Table 1) of the skin have been demonstrated in humans [24], pigs [88] and dogs [52, 53]. T cells are the main players in cell-mediated immune responses and cluster of differentiation (CD) $4^{+} \mathrm{T}$ cells have been demonstrated as the most prevalent $\mathrm{T}$ lymphocytes in inflammatory skin lesions in OS (Table 1) in humans $[89,90]$ pigs and dogs $[52,88]$. This corresponds to inflammatory cells in the skin lesions from patients with atopic dermatitis where a significantly greater number of infiltrating $\mathrm{CD} 4^{+}$lymphocytes compared with $\mathrm{CD}^{+}$subtypes is reported with $\mathrm{CD}^{+} / \mathrm{CD}^{+}$ratios similar to peripheral blood levels [91].

In contrast, immunohistology and flow cytometry studies using biopsies from CS skin lesions of humans and pigs have revealed increased number of infiltrating $\mathrm{CD}^{+} \mathrm{T}$ cells (Table 1) compared with minimal or no $\mathrm{CD} 4^{+}$cells in the skin dermis $[24,88]$. The number of $\mathrm{T}$ and $\mathrm{B}$ lymphocytes and T-cell subsets in the blood of CS patients have been reported within normal ranges [14, 24]. This presence of a greater number of $\mathrm{CD} 8^{+} \mathrm{T}$ cells in the skin than in the blood suggests a selective movement of $\mathrm{CD}^{+} \mathrm{T}$ cells. It is further hypothesised $[24,35]$ that these $\mathrm{CD}^{+} \mathrm{T}$ lymphocytes might be the cause of keratinocytes apoptosis leading to epidermal hyper-proliferation. This has also been observed in psoriasis patients with marked levels of $\mathrm{CD}^{+} \mathrm{T}$ cells in the skin epidermis and dermis [92]. The apoptotic keratinocytes may secrete cytokines which could exacerbate the inflammatory response by targeting resident skin cells causing further tissue damage. Therefore, these skin homing cytotoxic $\mathrm{T}$ cells may be responsible for the imbalanced inflammatory response and may contribute to the failure of the skin immune system to induce an effective response resulting in uncontrolled growth of the parasite. The precise role, importance and function of $\mathrm{CD}^{+} \mathrm{T}$ cells in the pathogenesis of CS needs to be investigated. Additionally, $\mathrm{CD} 4^{+} \mathrm{T}$ cells in the skin may be essential in the immune response to scabies conferring protection as it has been seen that acquired immunodeficiency syndrome (AIDS) patients often develop CS if infected with scabies mites [93, 94].

Recently our group reported that PBMC gamma delta $(\gamma \delta)^{+} \mathrm{T}$ cells increased in mange infected pigs relative to controls from as early as one week post mite infestation with these increases sustained throughout the infestation [88]. Similarly, strong PBMC proliferation of $\gamma \delta^{+}$T cells was reported in cattle infested with $P$. ovis [33]. These peripheral blood responses mirrored cutaneous responses, with skin cell infiltrates in the lesions of CS pigs showing significantly higher $\gamma \delta^{+} \mathrm{T}$ cell numbers than those with OS [88]. These elevated numbers of $\gamma \delta^{+} \mathrm{T}$ cells suggest their role in the disease pathogenesis as it has been demonstrated that IL-17 secretion by $\gamma \delta^{+} \mathrm{T}$ cells plays a critical role in the pathogenesis of psoriasis [95].

\section{Cytokine profiles in ordinary and crusted scabies}

Cytokines, chemokines, and other mediators secreted by $\mathrm{CD}^{+}$(Th1, Th2, Th17 and Tregs) and $\mathrm{CD}^{+} \mathrm{T}$ cells along with other effector cells orchestrate the immune and inflammatory responses to scabies mite or its products (Table 2). These cells and their secreted molecules have been associated with specific immune responses 
Table 2 Effect of scabies mites or mite extracts on key cytokines and molecules from cultured cells in vitro and in vivo

\begin{tabular}{|c|c|c|c|}
\hline Cell type(s) & Cytokines upregulated & Cytokines downregulated & Reference \\
\hline \multicolumn{4}{|l|}{ Cultured cells treated with mite extracts } \\
\hline Human skin equivalents (HSE) & $\begin{array}{l}\text { CTACK, IL 1a, IL 13, IL 1Ra, IL-6, IL-8, IL-23A, } \\
\text { GM-CSF, M-CSF }\end{array}$ & Not reported & {$[18,83]$} \\
\hline $\begin{array}{l}\text { Human dermal microvascular endothelial } \\
\text { cells (HMVEC-D) }\end{array}$ & ICAM-1 & IL-6, IL-8, VCAM-1 & {$[114,122]$} \\
\hline Human keratinocytes, fibroblasts & IL-6, CTACK, TGF a, CXCL1, G-CSF & IL-8, GM-CSF & {$[84,113]$} \\
\hline Dendritic cells & TNF-a & IL-6, IL-8 & [60] \\
\hline \multicolumn{4}{|l|}{ In vivo studies: humans } \\
\hline PBMCs & $\begin{array}{l}\text { IL-10, IFN- } \gamma, \text { IL-6, IL-8, TNF-a, IL 1 } \beta, \text { IL-4, } \\
\text { IL-5, IL-13 }\end{array}$ & $\| \mathrm{L}-10$ & {$[35,46,57]$} \\
\hline Serum & IL-10, TNF-a, IFN- $\gamma$ & IL-6 & [47] \\
\hline Skin biopsies (crusted scabies) & IL-1 $\beta$, TGF- $\beta$ & IFN-y, IL-10? & [23] \\
\hline \multicolumn{4}{|l|}{ In vivo studies: other animals } \\
\hline Porcine PBMCs & IL-17, IFN- $\gamma$ & Not reported & [88] \\
\hline Spleen (from exposed/vaccinated mice) & G-CSF, IL-2, IL-13 & $\begin{array}{l}\text { ICAM-1, ICAM-2, L-selectin, M-CSF, } \\
\text { TNF a, TGF } \beta\end{array}$ & [112] \\
\hline Canine PBMCs & $\|L-4\| L-5,, T G F-\beta$ & TNF-a & [123] \\
\hline Pig skin biopsies & IL-13, IL-17, IL-23, IL-4, IL-2, TGF- $\beta$ & Not reported & [46] \\
\hline
\end{tabular}

and have been implicated in various inflammatory skin and infectious diseases.

Scabies mite infestation skews the Th1/Th2 immune response [96]. It is suggested that the host immune response to OS is a Th1 cell-mediated protective response. Th1-biased immune responses are dominated by $\mathrm{CD} 4^{+}$ and $\mathrm{CD}^{+} \mathrm{T}$ cells secreting the cytokines IFN- $\gamma, \mathrm{TNF}-\alpha$ and IL-2 $[97,98]$. Studies have shown strong IFN- $\gamma$ and TNF- $\alpha$ proliferative responses in PBMCs to scabies mite antigens [35] and studies have shown the presence of these cytokines in the serum of OS patients [51].

Th2 cells secrete IL-4, IL-5 and IL-13, and mediate humoral immunity by upregulating antibody production to fight extracellular parasites. Th2 cells are also dominant effector cells in the pathogenesis of IgE-mediated hypersensitivity in asthma and other allergic inflammatory diseases. PBMCs isolated from CS patients secreted increased levels of Th2 cytokines IL-4, IL-5 and IL-13, and decreased secretion of the Th1 cytokine IFN- $\gamma$ as compared to OS upon stimulation with scabies mite antigens [35], similar to those seen with Der p 1 and HDM allergy [99]. Transcriptional analysis of skin biopsies from pigs with CS and cattle susceptible to severe psoroptic mange similarly revealed increased expression of IL-4, IL-5 and IL-13 [33, 46]. IL-4 and IL-13 play important roles in class switching of $\mathrm{B}$ cells and induce coexpression of IgE and IgG4 [100, 101], and thus the presence of these cytokines in CS is in alignment with the extremely high levels of IgG4 and IgE observed [14]. This strong humoral response in severe CS is not surprising given the antigenic load imparted by the hyper- proliferation of scabies mite. However, this Th2 skewed response may be a cause of rather than a response to scabies mite infestation, as porcine studies have demonstrated upregulation of these cytokines relatively early in infestation before mite numbers reach extremely high levels [46].

IL-17 is a potent proinflammatory cytokine, commonly recognised to be secreted by Th17 cells but it is also secreted by other cell types such as $\gamma \delta^{+}$and $\mathrm{CD}^{+} \mathrm{T}$ cells. Th17 cell generation and IL-17 secretion is promoted through cytokine signalling, in particular by IL-6, TGF$\beta$, IL-23 and IL-1 $\beta$ or IL-18 [102]. Studies have demonstrated increased TGF- $\beta$, IL-23 and IL-1 $\beta$ expression in immune response to scabies mite infestation $[18,46]$, indicating that there are immune signals available in the local skin environment which may foster the generation of IL-17 secreting T cells. Furthermore, our group has shown increased IL-17 and IL-23 production in T cells isolated from skin lesions of pigs with CS [46, 88] and high levels of IL-17 have also been documented in the skin lesions of cattle breeds susceptible to psoroptic mange but not in those breeds resistant to Psoroptes infestation [33]. IL-17 secretion further exacerbates the ongoing inflammatory responses by inducing expression of TNF- $\alpha$, IL- $1 \beta$ and IL- 6 in epithelial cells as well as keratinocytes and fibroblasts [103]. Th17 cells and the cytokine IL-17 play a critical role in the inflammatory pathology associated with skin diseases, such as psoriasis and atopic dermatitis [104, 105] and parasitic Leishmania major and Schistosoma japonicum infections [106, 107]. 
TGF- $\beta$ and IL-10 secreted by Tregs suppress pathological inflammatory responses [108]. It is suggested that Tregs may play a role in the control or development of scabies [88]. In CS, it has been demonstrated that IL-10 secretion in both PBMCs and lesional skin is significantly reduced compared to OS and control cases [24, 35]. In agreement with this, Abd El-Aal et al. [51] reported a negative correlation between IL-10 secretion and severity of lesions in ordinary scabies. It has been postulated that the activity of Tregs and IL-10 secretion [47] in OS cases may contribute to inhibition of inflammatory and immune reactions to the parasite which may partially explain the 4-6 week incubation period in a primary infestation of $S$. scabiei. It has been demonstrated in PBMCs that scabies mite extract can induce IL-10 expression and by extrapolation, influence Tregs activity [109]. The delay in symptoms may also be in part due to the well-known ability of IL-10 in inhibiting synthesis of the proinflammatory cytokines TNF- $\alpha$, IFN- $\gamma$ an IL-2 $[110,111]$. It is suggested that this reduced IL-10 expression may cause expansion of IL-17-secreting T cells resulting in a Treg/ Th17 dysfunctional immune response. Such a hypothesis is supported by a recent murine study of mucocutaneous leishmaniosis, where blocking of IL-10R resulted in increased IL-17 responses and more severe skin pathology [106].

\section{Summary, recent developments and future directions}

In summary, our current understanding indicates that the immune responses to scabies are complex, with distinct profiles between the different clinical manifestations (summarised in Fig. 1, Table 1). Crusted scabies

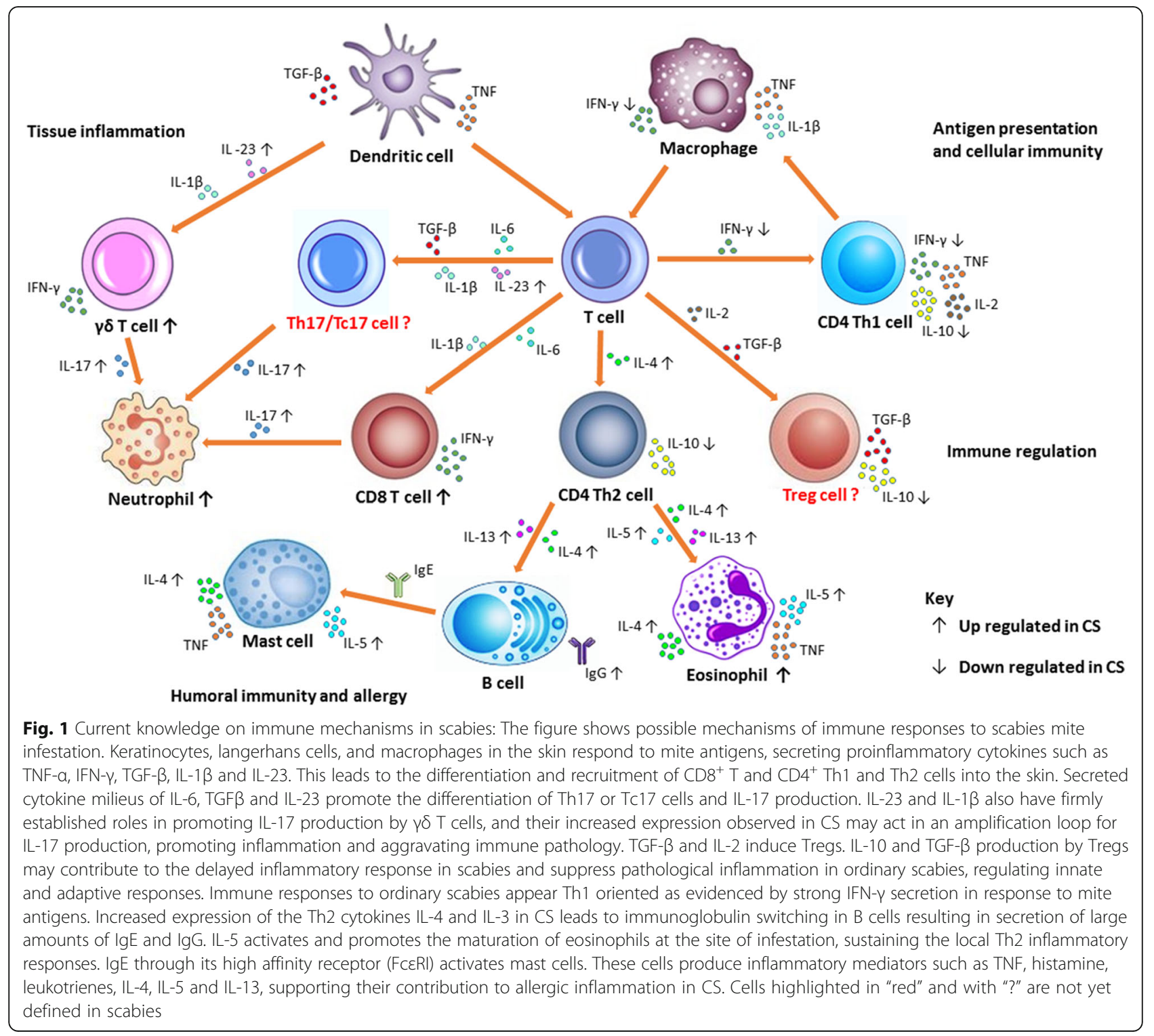


shows a picture of increased $\mathrm{CD} 8^{+}$and $\gamma \delta^{+} \mathrm{T}$ cell infiltration [24, 88], increased production of IgE [14, 24, 35], elevated secretion of Th2 cytokines IL4, IL-5 and IL-13, decreased IL-10 production [35] and increased production of Th17 cytokines IL-17 and IL-23 [88] suggesting a mix of non-protective allergic Th2 and IL-17 responses contributing in disease pathogenesis. However, the underlying mechanisms of these elevated responses in CS is not yet known and the knowledge about these events is important in understanding the development and immunological progression in CS. Although CS is often associated with general immunosuppressive conditions such as HIV, HTLV-1 infections, or patients undergoing organ transplantation, some people with no recognised immunodeficiency still develop CS [14]. In addition, studies with pigs have shown that some pigs develop OS while others exhibit CS phenotype after infestation following inoculation with a similar number of mites $[65,88]$. This indicates that these individuals/animals may have an immunity related genetic predisposition increasing susceptibility to CS. These genetic changes may not directly cause CS but may play a role in its development. Detailed gene expression studies would be beneficial for identifying such genetic changes, particularly if conducted early in infestation, prior to the development of high mite burdens and severe clinical pathology with confounding co-morbidities.

One of the characteristic features of a primary $S$. scabiei infestation is that clinical signs of cutaneous inflammation and pruritus do not appear until weeks after infestation. Studies show that S. scabiei may be inhibiting the early immune responses by downregulating the expression of proinflammatory mediators and cytokines [18, 60, 112-114]. However, these studies were mostly in vitro, utilising mite extracts and cultured cells or skin equivalents.

To gain valuable insights into the mechanisms behind the immune and inflammatory responses driving disease outcomes in scabies, it is highly imperative to look into the immune responses upstream of those seen at clinical presentation, with in vivo prospective studies. As access to patients with scabies is very limited and carrying out a study of infection in humans can be logistically and ethically a difficult process, thus animal models provide an alternative to investigate the immunopathological mechanisms of scabies development. In addition to studies undertaken with experimental infestation in dogs $[52,53]$ and rabbits [66], a model involving pigs has been recently utilised [115]. Pigs are a natural host to $S$. scabiei var. suis and develop clinical manifestations resembling both CS and OS, making this model preferable for comparative immunology studies [116].

This porcine model has already allowed more detailed study of scabies immunology than previously possible and importantly validated critical findings from human crusted scabies where interpretation was limited by small sample numbers. Further studies have also begun to shed some light into the effect of scabies mite infestation on the skin microbiota, and helping to unravel the complexities between S. scabiei and concomitant bacterial infection [117]. Recent genome sequencing [118, 119] and proteomic analysis $[120,121]$ of S. scabiei promises to provide further insights in understanding the biology of the mite, molecular basis of host specificity, hostparasite interactions, parasitic adaptations and immune evasion. The knowledge of host immune responses and genetic changes in scabies is essential and may aid in the development of novel therapeutics, diagnostic and disease control, as well as allow the early discrimination of ordinary scabies from the severe form of the disease.

\section{Conclusion}

In conclusion, development of immunodiagnostics, vaccines, and immunotherapeutic represents a promising long term strategy to control scabies in affected communities globally. A comprehensive understanding of the immune events in the skin and peripheral blood occurring during scabies may provide multiple points at which immunological interventions may intersect the infection and target the responses away from pathology to immunity.

\section{Abbreviations \\ AIDS: Acquired Immunodeficiency Syndrome; C: Complement; CD: Cluster of differentiation; CS: Crusted scabies; CTACK: Cutaneous T-cell-attracting chemokine; CXCL: Chemokine (C-X-C motif) ligand; DC: Dendritic cell; ELISA: Enzyme-linked immunosorbent assay; GM-CSF: Granulocyte-macrophage colony-stimulating factor; ICAM: Intercellular adhesion molecule; IFN- \\ ү: Interferon- $\gamma$; Ig: Immunoglobulin; IL-10: Interleukin-10; IL-12: Interleukin-12; IL- 13: Interleukin-13; IL-18: Interleukin-18; IL-1 B: Interleukin-1 beta; IL-2: Interleukin 2; IL-22: Interleukin-22; IL-23: Interleukin-23; IL-4: Interleukin-4; IL-5: Interleukin-5; IL-6: Interleukin-6; IL-8: Interleukin-8; M-CSF: Macrophage colony-stimulating fac- tor; OS: Ordinary scabies; PBMCs: Peripheral blood mononuclear cells; SMIPPs: Scabies mite proteases; SMSs: Scabies mite serpins; TGF- $\beta$ : Transforming growth factor-beta; Th: T helper; TNF: Tumour necrosis factor; Tregs: Regulatory T cells; $\Gamma \delta:$ Gamma delta}

\section{Acknowledgements}

Not applicable.

\section{Funding}

KEM was supported by Australian Research Council Discovery Early Career Researcher Award. SAB was supported by a doctoral scholarship granted by the University of the Sunshine Coast, QLD Australia.

\section{Availability of data and materials \\ Not applicable.}

\section{Authors' contributions}

$S A B, K M$ and SFW equally conceptualised the topic and development of this review. SAB performed literature searches and wrote the manuscript. KM, $\mathrm{XL}$ and SFW edited the manuscript. All authors have read and approved the final manuscript.

Ethics approval and consent to participate Not applicable. 


\section{Consent for publication}

Not applicable.

\section{Competing interests}

The authors declare that they have no competing interests.

\section{Publisher's Note}

Springer Nature remains neutral with regard to jurisdictional claims in published maps and institutional affiliations.

Received: 2 January 2017 Accepted: 2 August 2017 Published online: 10 August 2017

\section{References}

1. Hicks MI, Elston DM. Scabies. Dermatol Ther. 2009;22(4):279-92.

2. Hay RJ, Johns NE, Williams HC, Bolliger IW, Dellavalle RP, Margolis DJ, et al. The global burden of skin disease in 2010: an analysis of the prevalence and impact of skin conditions. J Invest Dermatol. 2014;134(6):1527-34.

3. Romani L, Steer AC, Whitfeld MJ, Kaldor JM. Prevalence of scabies and impetigo worldwide: a systematic review. Lancet Infect Dis. 2015;15(8):960-7.

4. Murray CJ, Vos T, Lozano R, Naghavi M, Flaxman AD, Michaud C, et al. Disability-adjusted life years (DALYs) for 291 diseases and injuries in 21 regions, 1990-2010: a systematic analysis for the global burden of disease study 2010. Lancet. 2012:380(9859):2197-223.

5. Hoy WE, White AV, Dowling A, Sharma SK, Bloomfield H, Tipiloura BT, et al. Post-streptococcal glomerulonephritis is a strong risk factor for chronic kidney disease in later life. Kidney Int. 2012;81:1026-32.

6. Engelman D, Kiang K, Chosidow O, McCarthy J, Fuller C, Lammie P, et al. Toward the global control of human scabies: introducing the international alliance for the control of scabies. PLoS Negl Trop Dis. 2013;7(8):e2167.

7. Mellanby K. Transmission of scabies. Br Med J. 1941;2(4211):405-6.

8. Wendel K, Rompalo A. Scabies and pediculosis pubis: an update of treatment regimens and general review. Clin Infect Dis. 2002;35(Suppl 2):S146-51.

9. McCarthy JS, Kemp DJ, Walton SF, Currie BJ. Scabies: more than just an irritation. Postgrad Med J. 2004:80(945):382-7.

10. Walton SF, Currie BJ, Kemp DJ. A DNA fingerprinting system for the ectoparasite Sarcoptes scabiei. Mol Biochem Parasitol. 1997;85(2):187-96.

11. Mounsey KE, Murray HC, King M, Oprescu F. Retrospective analysis of institutional scabies outbreaks from 1984 to 2013: lessons learned and moving forward. Epidemiol Infect. 2016;144(11):2462-71.

12. Hulbert TV, Larsen RA. Hyperkeratotic (Norwegian) scabies with gramnegative bacteremia as the initial presentation of AIDS. Clin Infect Dis. 1992;14(5):1164-5.

13. Currie BJ, Carapetis JR. Skin infections and infestations in aboriginal communities in northern Australia. Australas J Dermatol. 2000;41(3):139-43.

14. Roberts LJ, Huffam SE, Walton SF, Currie BJ. Crusted scabies: clinical and immunological findings in seventy-eight patients and a review of the literature. J Inf Secur. 2005;50(5):375-81.

15. Einsiedel LJ, Pepperill C, Wilson K. Crusted scabies: a clinical marker of human T-lymphotropic virus type 1 infection in central Australia. Med J Aust. 2014;200(11):633-4

16. Youshock E, Glazer SD. Norwegian scabies in a renal transplant patient. JAMA. 1981:246(22):2608-9.

17. Gogna NK, Lee KC, Howe DW. Norwegian scabies in Australian aborigines Med J Aust. 1985;142(2):140-2.

18. Morgan MS, Arlian LG, Markey MP. Sarcoptes scabiei mites modulate gene expression in human skin equivalents. PLoS One. 2013;8(8):e71143.

19. Cote NM, Jaworski DC, Wasala NB, Morgan MS, Arlian LG. Identification and expression of macrophage migration inhibitory factor in Sarcoptes scabiei. Exp Parasitol. 2013;135(1):175-81.

20. Walton SF. The immunology of susceptibility and resistance to scabies. Parasite Immunol. 2010;32(8):532-40.

21. Ricklin D, Hajishengallis G, Yang K, Lambris JD. Complement: a key system for immune surveillance and homeostasis. Nat Immunol. 2010;11(9):785-97.

22. Wikel SK. Acquired resistance to ticks: expression of resistance by C4deficient guinea pigs. Am J Trop Med Hyg. 1979:28(3):586-90.

23. Zipfel PF, Wurzner R, Skerka C. Complement evasion of pathogens: common strategies are shared by diverse organisms. Mol Immunol. 2007:44(16):3850-7.
24. Walton SF, Beroukas D, Roberts-Thomson P, Currie BJ. New insights into disease pathogenesis in crusted (Norwegian) scabies: the skin immune response in crusted scabies. Br J Dermatol. 2008;158(6):1247-55.

25. Janeway CAJ, Travers P, Walport M, Shlomchik MJ. The complement system and innate immunity. In: Sarah G, editor. Immunobiology: the immune system in health and disease. New York: Garland Science; 2001.

26. Mika A, Reynolds SL, Pickering D, McMillan D, Sriprakash KS, Kemp DJ, Fischer K. Complement inhibitors from scabies mites promote streptococcal growth - a novel mechanism in infected epidermis? PLoS Negl Trop Dis. 2012;6(7):e1563.

27. Swe PM, Fischer K. A scabies mite serpin interferes with complementmediated neutrophil functions and promotes staphylococcal growth. PLoS Negl Trop Dis. 2014:8(6):e2928.

28. Holt DC, Fischer K. Novel insights into an old disease: recent developments in scabies mite biology. Curr Opin Infect Dis. 2013;26(2):110-5.

29. Swe PM, Zakrzewski M, Kelly A, Krause L, Fischer K. Scabies mites alter the skin microbiome and promote growth of opportunistic pathogens in a porcine model. PLoS Negl Trop Dis. 2014;8(5):e2897.

30. Prussin C, Metcalfe DD. IgE, mast cells, basophils, and eosinophils. J Allergy Clin Immunol. 2006;117(Suppl 2 Mini-Primer):S450-6.

31. Elwood H, Berry RS, Gardner JM, Shalin SC. Superficial fibrin thrombi ... and other findings: a review of the histopathology of human scabetic infections. J Cutan Pathol. 2015;42(5):346-52.

32. van den Broek AH, Huntley JF, MacHell J, Taylor M, Bates P, Groves B, Miller HR. Cutaneous and systemic responses during primary and challenge infestations of sheep with the sheep scab mite, Psoroptes ovis. Parasite Immunol. 2000;22(8):407-14.

33. Sarre C, Gonzalez-Hernandez A, Van Coppernolle S, Grit R, Grauwet K, Van Meulder F, et al. Comparative immune responses against Psoroptes ovis in two cattle breeds with different susceptibility to mange. Vet Res. 2015;46:131.

34. Little SE, Davidson WR, Rakich PM, Nixon TL, Bounous DI, Nettles VF. Responses of red foxes to first and second infection with Sarcoptes scabiei. J Wildl Dis. 1998;34(3):600-11.

35. Walton SF, Pizzutto S, Slender A, Viberg L, Holt D, Hales BJ, et al. Increased allergic immune response to Sarcoptes scabiei antigens in crusted versus ordinary scabies. Clin Vaccine Immunol. 2010;17(9):1428-38.

36. Hamelmann E, Gelfand EW. IL-5-induced airway eosinophilia - the key to asthma? Immunol Rev. 2001;179:182-91.

37. Voehringer D, Reese TA, Huang $X$, Shinkai $K$, Locksley RM. Type 2 immunity is controlled by IL-4/IL-13 expression in hematopoietic non-eosinophil cells of the innate immune system. J Exp Med. 2006;203(6):1435-46.

38. Cadman ET, Lawrence RA. Granulocytes: effector cells or immunomodulators in the immune response to helminth infection? Parasite Immunol. 2010:32(1):1-19.

39. Jacobsen EA, Taranova AG, Lee NA, Lee JJ. Eosinophils: singularly destructive effector cells or purveyors of immunoregulation? J Allergy Clin Immunol. 2007;119(6):1313-20

40. Lamkhioued B, Gounni AS, Aldebert D, Delaporte E, Prin L, Capron A, Capron M. Synthesis of type 1 (IFN gamma) and type 2 (IL-4, IL-5, and IL-10) cytokines by human eosinophils. Ann NY Acad Sci. 1996;796:203-8.

41. Nagase H, Okugawa S, Ota Y, Yamaguchi M, Tomizawa H, Matsushima K, et al. Expression and function of toll-like receptors in eosinophils: activation by toll-like receptor 7 ligand. J Immunol. 2003;171(8):3977-82.

42. Boyman $\mathrm{O}$, Sprent J. The role of interleukin-2 during homeostasis and activation of the immune system. Nat Rev Immunol. 2012;12(3):180-90.

43. Ohno I, Nitta Y, Yamauchi K, Hoshi H, Honma M, Woolley $K$, et al. Transforming growth factor beta 1 (TGF beta 1) gene expression by eosinophils in asthmatic airway inflammation. Am J Respir Cell Mol Biol. 1996:15(3):404-9.

44. Amer M, Mostafa FF, Nasr AN, el-Harras M. The role of mast cells in treatment of scabies. Int J Dermatol. 1995;34(3):186-9.

45. Ito Y, Satoh T, Takayama K, Miyagishi C, Walls AF, Yokozeki H. Basophil recruitment and activation in inflammatory skin diseases. Allergy. 2011;66(8):1107-13.

46. Mounsey KE, Murray HC, Bielefeldt-Ohmann H, Pasay C, Holt DC, Currie BJ, et al. Prospective study in a porcine model of sarcoptes scabiei indicates the association of Th2 and Th17 pathways with the clinical severity of scabies. PLoS Negl Trop Dis. 2015;9(3):e0003498.

47. Nimmervoll H, Hoby S, Robert N, Lommano E, Welle M, Ryser-Degiorgis MP. Pathology of sarcoptic mange in red foxes (Vulpes vulpes): macroscopic and histologic characterization of three disease stages. J Wildl Dis. 2013;49(1):91-102. 
48. Skerratt LF. Cellular response in the dermis of common wombats (Vombatus ursinus) infected with Sarcoptes scabiei var. wombati. J Wild Dis. 2003;39(1):193-202.

49. Schroeder JT. Basophils: emerging roles in the pathogenesis of allergic disease. Immunol Rev. 2011;242(1):144-60.

50. Brombacher $\mathrm{F}$. The role of interleukin-13 in infectious diseases and allergy. BioEssays. 2000;22(7):646-56.

51. Abd El-Aal AA, Hassan MA, Gawdat HI, Ali MA, Barakat M. Immunomodulatory impression of anti and pro-inflammatory cytokines in relation to humoral immunity in human scabies. Int J Immunopathol Pharmacol. 2016;29(2):188-94.

52. Arlian LG, Rapp CM, Stemmer BL, Morgan MS, Moore PF. Characterization of lymphocyte subtypes in scabietic skin lesions of naive and sensitized dogs Vet Parasitol. 1997;68(4):347-58

53. Stemmer BL, Arlian LG, Morgan MS, Rapp CM, Moore PF. Characterization of antigen presenting cells and T-cells in progressing scabietic skin lesions. Vet Parasitol. 1996;67(3-4):247-58.

54. Barrett NA, Austen KF. Innate cells and T helper 2 cell immunity in airway inflammation. Immunity. 2009:31(3):425-37.

55. Hahn J, Knopf J, Maueroder C, Kienhofer D, Leppkes M, Herrmann M. Neutrophils and neutrophil extracellular traps orchestrate initiation and resolution of inflammation. Clin Exp Rheumatol. 2016;34(4 Suppl 98):6-8.

56. Luo DQ, Huang MX, Liu JH, Tang W, Zhao YK, Sarkar R. Bullous scabies. Am J Trop Med Hyg. 2016;95(3):689-93.

57. Dagleish MP, Ali Q, Powell RK, Butz D, Woodford MH. Fatal Sarcoptes scabiei infection of blue sheep (Pseudois nayaur) in Pakistan. J Wildl Dis. 2007:43(3):512-7.

58. Hunger RE, Sieling PA, Ochoa MT, Sugaya M, Burdick AE, Rea TH, et al. Langerhans cells utilize CD1a and langerin to efficiently present nonpeptide antigens to T cells. J Clin Invest. 2004;13(5):701-8.

59. Loser K, Beissert S. Dendritic cells and T cells in the regulation of cutaneous immunity. Adv Dermatol. 2007:23:307-33.

60. Arlian LG, Morgan MS, Neal JS. Extracts of scabies mites (Sarcoptidae: Sarcoptes scabiei) modulate cytokine expression by human peripheral blood mononuclear cells and dendritic cells. J Med Entomol. 2004;41(1):69-73.

61. Arlian LG, Feldmeier H, Morgan MS. The potential for a blood test for scabies. PLoS Negl Trop Dis. 2015;9(10):e0004188.

62. Arlian LG, Morgan MS, Vyszenski-Moher DL, Stemmer BL. Sarcoptes scabiei: the circulating antibody response and induced immunity to scabies. Exp Parasitol. 1994:78(1):37-50.

63. Morsy TA, Kenawi MZ, Zohdy HA, Abdalla KF, el Fakahany AF. Serum immunoglobulin and complement values in scabietic patients. J Egypt Soc Parasitol. 1993;23(1):221-9.

64. Kenawi MZ, Morsy TA, Abdalla KF, Nasr ME, Awadalla RA. Clinical and parasitological aspects on human scabies in Qualyobia Governorate, Egypt. J Egypt Soc Parasitol. 1993;23(1):247-53.

65. Rampton M, Walton SF, Holt DC, Pasay C, Kelly A, Currie BJ, et al. Antibody responses to Sarcoptes scabiei apolipoprotein in a porcine model: relevance to immunodiagnosis of recent infection. PLoS One. 2013:8(6):e65354.

66. Morgan MS, Arlian LG. Serum antibody profiles of Sarcoptes scabiei infested or immunized rabbits. Folia Parasitol. 1994;41(3):223-7.

67. Arlian LG, Morgan MS, Rapp CM, Vyszenski-Moher DL. The development of protective immunity in canine scabies. Vet Parasitol. 1996;62(1-2):133-42.

68. Arlian LG, Morgan MS. Serum antibody to Sarcoptes scabiei and house dust mite prior to and during infestation with S. scabiei. Vet Parasitol. 2000;90(4):315-26

69. Rodriguez-Cadenas F, Carbajal-Gonzalez MT, Fregeneda-Grandes JM, AllerGancedo JM, Rojo-Vazquez FA. Clinical evaluation and antibody responses in sheep after primary and secondary experimental challenges with the mange mite Sarcoptes scabiei var. ovis. Vet Immunol Immunopathol. 2010;133(2-4):109-16.

70. Tarigan S. Antibody responses in naive and sensitised goats infested by Sarcoptes scabiei. Jurnal IImu Ternak dan Veteriner. 2004;9:258-65.

71. Sarasa M, Rambozzi L, Rossi L, Meneguz PG, Serrano E, Granados JE, et al. Sarcoptes scabiei: specific immune response to sarcoptic mange in the Iberian ibex Capra pyrenaica depends on previous exposure and sex. Exp Parasitol. 2010;24(3):265-71.

72. Bornstein S, Zakrisson G. Humoral antibody response to experimental Sarcoptes scabiei var. vulpes infection in the dog. Vet Dermatol. 1993;4(3):107-10.

73. Casais R, Dalton KP, Millan J, Balseiro A, Oleaga A, Solano P, et al. Primary and secondary experimental infestation of rabbits (Oryctolagus cuniculus) with Sarcoptes scabiei from a wild rabbit: factors determining resistance to reinfestation. Vet Parasitol. 2014;203(1-2):173-83.

74. Arlian LG, Morgan MS, Estes SA, Walton SF, Kemp DJ, Currie BJ. Circulating IgE in patients with ordinary and crusted scabies. J Med Entomol. 2004:41(1):74-7.

75. Dougall A, Holt DC, Fischer K, Currie BJ, Kemp DJ, Walton SF. Identification and characterization of Sarcoptes scabiei and Dermatophagoides pteronyssinus glutathione S-transferases: implication as a potential major allergen in crusted scabies. Am J Trop Med Hyg. 2005;73(5):977-84.

76. Aalberse RC, Stapel SO, Schuurman J, Rispens T. Immunoglobulin G4: an odd antibody. Clin Exp Allergy. 2009;39(4):469-77.

77. Collins AM, Jackson KJ. A temporal model of human IgE and IgG antibody function. Front Immunol. 2013;4:235.

78. Falk ES. Serum immunoglobulin values in patients with scabies. $\mathrm{Br}$ Dermatol. 1980;102(1):57-61.

79. Hancock BW, Ward AM. Serum immunoglobulin in scabies. J Invest Dermatol. 1974;63(6):482-4

80. Jayaraj $R$, Hales B, Viberg L, Pizzuto S, Holt D, Rolland JM, et al. A diagnostic test for scabies: IgE specificity for a recombinant allergen of Sarcoptes scabiei. Diagn Microbiol Infect Dis. 2011:71(4):403-7.

81. Falk ES. Serum IgE before and after treatment for scabies. Allergy. 1981:36(3):167-74.

82. Walton SF, Slender A, Pizutto S, Mounsey KE, Opresecu F, Thomas WR, et al. Analysis of lgE binding patterns to house dust mite allergens in scabiesendemic communities: insights for both diseases. Clin Exp Allergy. 2015;45(12):1868-72.

83. Morgan MS, Arlian LG. Response of human skin equivalents to Sarcoptes scabiei. J Med Entomol. 2010;47(5):877-83.

84. Mullins JS, Arlian LG, Morgan MS. Extracts of Sarcoptes scabiei de Geer downmodulate secretion of IL-8 by skin keratinocytes and fibroblasts and of GM-CSF by fibroblasts in the presence of proinflammatory cytokines. J Med Entomol. 2009;46(4):845-51.

85. Hagan P, Blumenthal UJ, Dunn D, Simpson AJ, Wilkins HA. Human IgE, IgG4 and resistance to reinfection with Schistosoma haematobium. Nature. 1991:349(6306):243-5.

86. Hagan P. IgE and protective immunity to helminth infections. Parasite Immunol. 1993;15(1):1-4.

87. Nyindo M, Kariuki TM, Mola PW, Farah IO, Elson L, Blanton RE, King CL. Role of adult worm antigen-specific immunoglobulin $E$ in acquired immunity to Schistosoma mansoni infection in baboons. Infect Immun. 1999;67(2):636-42

88. Liu X, Walton SF, Murray HC, King M, Kelly A, Holt DC, et al. Crusted scabies is associated with increased IL-17 secretion by skin T cells. Parasite Immunol. 2014;36(11):594-604.

89. Falk ES, Eide TJ. Histologic and clinical findings in human scabies. Int J Dermatol. 1981;20(9):600-5.

90. Falk ES, Matre R. In situ characterization of cell infiltrates in the dermis of human scabies. Am J Dermatopathol. 1982;4(1):9-15.

91. Akdis CA, Akdis M, Simon D, Dibbert B, Weber M, Gratzl S, et al. T cells and T cell-derived cytokines as pathogenic factors in the nonallergic form of atopic dermatitis. J Invest Dermatol. 1999;113(4):628-34.

92. Bovenschen HJ, Seyger MM, Van de Kerkhof PC. Plaque psoriasis vs. atopic dermatitis and lichen planus: a comparison for lesional T-cell subsets, epidermal proliferation and differentiation. Br J Dermatol. 2005;153(1):72-8.

93. Fuchs BS, Sapadin AN, Phelps RG, Rudikoff D. Diagnostic dilemma: crusted scabies superimposed on psoriatic erythroderma in a patient with acquired immunodeficiency syndrome. Skinmed. 2007;6(3):142-4.

94. Orkin M. Scabies in AIDS. Semin Dermatol. 1993;12(1):9-14.

95. Cai Y, Shen X, Ding C, Qi C, Li K, Li X, et al. Pivotal role of dermal IL-17producing gammadelta $T$ cells in skin inflammation. Immunity. 2011:35(4):596-610.

96. Lalli PN, Morgan MS, Arlian LG. Skewed Th1/Th2 immune response to Sarcoptes scabiei. J Parasitol. 2004;90(4):711-4.

97. Romagnani S. T-cell subsets (Th1 versus Th2). Ann Allergy Asthma Immunol. 2000:85(1):9-18.

98. Kidd P. Th1/Th2 balance: the hypothesis, its limitations, and implications for health and disease. Altern Med Rev. 2003:8(3):223-46.

99. Thomas WR, Hales BJ, Smith WA. Recombinant allergens for analysing T-cell responses. Methods. 2004:32(3):255-64.

100. Coffman RL, Ohara J, Bond MW, Carty J, Zlotnik A, Paul WE. B cell stimulatory factor-1 enhances the lgE response of lipopolysaccharide-activated B cells. J Immunol. 1986;136(12):4538-41. 
101. Punnonen J, de Vries JE. IL-13 induces proliferation, Ig isotype switching, and Ig synthesis by immature human fetal B cells. J Immunol. 1994;152(3):1094-102.

102. McGeachy MJ, Cua DJ. Th17 cell differentiation: the long and winding road. Immunity. 2008;28(4):445-53.

103. Fouser LA, Wright JF, Dunussi-Joannopoulos K, Collins M. Th17 cytokines and their emerging roles in inflammation and autoimmunity. Immunol Rev. 2008;226:87-102

104. Di Cesare A, Di Meglio P, Nestle FO. A role for Th17 cells in the immunopathogenesis of atopic dermatitis? J Invest Dermatol. 2008;128(11):2569-71

105. Di Cesare A, Di Meglio P, Nestle FO. The IL-23/Th17 axis in the immunopathogenesis of psoriasis. J Invest Dermatol. 2009;129(6):1339-50.

106. Gonzalez-Lombana C, Gimblet C, Bacellar O, Oliveira WW, Passos S, Carvalho $L P$, et al. IL-17 mediates immunopathology in the absence of IL-10 following Leishmania major infection. PLoS Pathog. 2013;9(3):e1003243.

107. Chen D, Luo X, Xie H, Gao Z, Fang H, Huang J. Characteristics of IL-17 induction by Schistosoma japonicum infection in C57BL/6 mouse liver. Immunology. 2013;139(4):523-32.

108. Miyara M, Sakaguchi S. Human FoxP3(+) CD4(+) regulatory T cells: their knowns and unknowns. Immunol Cell Biol. 2011:89(3):346-51.

109. Arlian LG, Morgan MS, Paul CC. Evidence that scabies mites (Acari: Sarcoptidae) influence production of interleukin-10 and the function of Tregulatory cells (Tr1) in humans. J Med Entomol. 2006;43(2):283-7.

110. Moore KW, de Waal MR, Coffman RL, O'Garra A. Interleukin-10 and the interleukin-10 receptor. Annu Rev Immunol. 2001;19:683-765.

111. O'Garra A, Vieira PL, Vieira P, Goldfeld AE. IL-10-producing and naturally occurring CD4+ Tregs: limiting collateral damage. J Clin Invest. 2004;114(10):1372-8.

112. Arlian LG, Fall N, Morgan MS. In vivo evidence that Sarcoptes scabiei (Acari: Sarcoptidae) is the source of molecules that modulate splenic gene expression. J Med Entomol. 2007;44(6):1054-63.

113. Arlian LG, Morgan MS, Neal JS. Modulation of cytokine expression in human keratinocytes and fibroblasts by extracts of scabies mites. Am J Trop Med Hyg. 2003;69(6):652-6.

114. Elder BL, Arlian LG, Morgan MS. Sarcoptes scabiei (Acari: Sarcoptidae) mite extract modulates expression of cytokines and adhesion molecules by human dermal microvascular endothelial cells. J Med Entomol. 2006;43(5):910-5.

115. Mounsey K, Ho MF, Kelly A, Willis C, Pasay C, Kemp DJ, et al. A tractable experimental model for study of human and animal scabies. PLoS Negl Trop Dis. 2010;4(7):e756.

116. Morsy GH, Turek JJ, Gaafar SM. Scanning electron microscopy of sarcoptic mange lesions in swine. Vet Parasitol. 1989;31(3-4):281-8.

117. Swe PM, Reynolds SL, Fischer K. Parasitic scabies mites and associated bacteria joining forces against host complement defence. Parasite Immunol. 2014:36(11):585-93.

118. Rider SD Jr, Morgan MS, Arlian LG. Draft genome of the scabies mite. Parasit Vectors. 2015;8:585

119. Mofiz E, Holt DC, Seemann T, Currie BJ, Fischer K, Papenfuss AT. Genomic resources and draft assemblies of the human and porcine varieties of scabies mites, Sarcoptes scabiei var. hominis and var. suis. Gigascience. 2016;5(1):23.

120. Arlian LG, Morgan MS, Rider SD Jr. Sarcoptes scabiei: genomics to proteomics to biology. Parasit Vectors. 2016;9(1):380.

121. Morgan MS, Arlian LG, Rider SD Jr, Grunwald WC Jr, Cool DR. A proteomic analysis of Sarcoptes scabiei (Acari: Sarcoptidae). J Med Entomol. 2016;53(3):553-61.

122. Elder BL, Arlian LG, Morgan MS. Modulation of human dermal microvascular endothelial cells by Sarcoptes scabiei in combination with proinflammatory cytokines, histamine, and lipid-derived biologic mediators. Cytokine. 2009;47(2):103-11

123. Singh SK, Dimri U, Sharma B, Saxena M, Kumari P. Assessment of the cytokine profile in peripheral blood mononuclear cells of naturally Sarcoptes scabiei var. canis infested dogs. Vet Parasitol. 2014;206(3-4):253-7.

\section{Submit your next manuscript to BioMed Central and we will help you at every step:}

- We accept pre-submission inquiries

- Our selector tool helps you to find the most relevant journal

- We provide round the clock customer support

- Convenient online submission

- Thorough peer review

- Inclusion in PubMed and all major indexing services

- Maximum visibility for your research

Submit your manuscript at www.biomedcentral.com/submit

) Biomed Central 